NANAEKE

Indonesian Journal of Early Childhood Education

Volume 2, Nomor 2, Desember 2019

\title{
PENINGKATAN KUALITAS PENDIDIKAN ANAK USIA DINI MELALUI MANAJEMEN ADMINISTRASI
}

\author{
Eka Damayanti \\ Jurusan Pendidikan Islam Anak Usia Dini \\ Fakultas Tarbiyah dan Keguruan, UIN Alauddin Makassar \\ e-mail: eka.damayanti@uin-alauddin.ac.id \\ Andi Rezeky Amaliah \\ Jurusan Pendidikan Islam Anak Usia Dini \\ Fakultas Tarbiyah dan Keguruan, UIN Alauddin Makassar \\ e-mail: a.rezekyamaliah24@gmail.com \\ Aeni Tasnim \\ Jurusan Pendidikan Islam Anak Usia Dini \\ Fakultas Tarbiyah dan Keguruan, UIN Alauddin Makassar \\ e-mail: aenitasnim99@gmail.com \\ Nur Ayu Susanti \\ Jurusan Pendidikan Islam Anak Usia Dini \\ Fakultas Tarbiyah dan Keguruan, UIN Alauddin Makassar \\ e-mail: nurayususanti29@gmail.com \\ Nurul Rezky \\ Jurusan Pendidikan Islam Anak Usia Dini \\ Fakultas Tarbiyah dan Keguruan, UIN Alauddin Makassar \\ e-mail: nurul.rezky04@gmail.com \\ Naldien Syarran \\ Jurusan Pendidikan Islam Anak Usia Dini \\ Fakultas Tarbiyah dan Keguruan, UIN Alauddin Makassar \\ e-mail: syarrannaldien@gmail.com
}

\begin{abstract}
Abstrak
Penelitian ini bertujuan untuk mengetahui pola pengelolaan manajemen administrasi di TK Amaliah BTN Tamarunang Indah II. Penelitian kualitatif jenis deskriptif ini mempunyai subjek yang menjadi informan yakni kepala sekolah, guru dan operator di TK Amaliah BTN Tamarunang Indah II. Data penelitian dikumpulkan melalui cara observasi, wawancara dan dokumentasi. Analisis data menggunakan teknik analisis data kualitatif model Miles dan Huberman. Hasil penelitian menunjukkan bahwa TK Amaliah telah memenuhi standar dalam manajemen administrasi yaitu: a) Mengatur program pengajaran, secara umum telah disusun dengan baik, hal ini terlihat adanya perencanaan program kegiatan pengajaran dengan menyusun rencana kegiatan sesuai ketentuan; b) Mengatur kesiswaan, mencakup kegiatan pencatatan tentang anak didik sejak anak masuk sampai
\end{abstract}


meninggalkan sekolah; c) Mengatur kepegawaian, meliputi menginventarisasi pegawai, mengusulkan formasi guru dan merencanakan, data guru honorer, supervisi pembelajaran, dan absen guru. d) Mengatur perlengkapan atau barang, mencatat secara rapi dan teratur, mengetahui keadaan perlengkapan dalam waktu singkat, dan mengaitkan kebutuhan barang yang diperlukan dengan program pengajaran dan proses belajar mengajar. e) Mengatur keuangan, mulai dari pencatatan, perencanaan, pelaksanaan, pengawasan dan pertanggung jawaban. Dengan demikian, manajemen administrasi yang baik telah dilakukan oleh pihak sekolah sebagai salah satu upaya penting dalam peningkatan kualitas pendidikan anak usia dini.

Kata Kunci: Kualitas Pendidikan; Manajemen Administrasi; Pendidikan Anak Usia Dini

\begin{abstract}
The aim of this research is to determine the design of administrative management in kindergarten Amaliah BTN Tamarunang Indah II. The research was a descriptive of qualitative with subjects as the informant, they are the principal, teachers and operators of the BTN Tamarunang Indah II Kindergarten Amaliah. The data were collected through observation, interviews and documentation and analyzed with Miles and Huberman's model. The results of the research show the Amaliah Kindergarten met the standards in administrative management, namely: a) Organizing the teaching program, where in general it arranged well. It can be seen from teaching activities planning programs according to the provisions; b) Organizing student activities, including activities record of the students during in school; c) Staffing, inventerisation, proposing teacher formation, making learning supervision, and preparing teacher absence. d) managing the equipment or goods supply, taking notes regularly, controlling the condition of equipment effectively, and managing the needs of teaching and learning process. e) Managing finance from recording, planning, implementing and supervising. The research indicates good administrative management in kindergarten Amaliah BTN Tamarunang Indah II. This is one of the important efforts in improving the quality of early childhood education.
\end{abstract}

Keywords: quality of education; administrative management; early childhood education programs

\title{
PENDAHULUAN
}

Anak usia dini merupakan anak yang berada pada rentang usia 0 - 6 tahun. Masa ini seringkali dikatakan anak dalam masa golden age karena pada masa ini semua pertumbuhan dan perkembangan mengalami kemajuan yang sangat pesat. Perkembangan itu sangat penting untuk perkembangan anak di masa yang akan datang. Hambatan perkembangan di masa ini pun sangat berpengaruh pada perkembangan anak, oleh karena itu seluruh pihak yang terlibat dalam stimulasi perkembangan anak pada masa usia dini perlu memaksimalkan usahanya agar anak dapat bertumbuh dan berkembang sesuai dengan tuntutan perkembangannya. 
Perkembangan yang dimaksud mulai dari perkembangan fisik motorik, kognitif, sosial emosi, nilai agama dan moral serta bahasa dan seni.

Stimulasi perkembangan pada anak usia dini dilakukan dalam lingkup keluarga dan dalam lingkup pendidikan formal yang biasa dalam lembaga satuan Pendidikan Anak Usia Dini (PAUD). Menurut El Fiah (2017) kehadiran PAUD sebagai suatu upaya pembinaan pemberian rangsangan pendidikan untuk membantu pertumbuhan dan perkembangan jasmani dan rohani agar anak memiliki kesiapan dalam memasuki pendidikan lebih. Lebih lanjut Khadijah (2016) mengungkapkan stimulasi pada anak usia dini sangat penting dilakukan karena perkembangan anak usia dini tidak bisa begitu saja dapat diulang kembali. Kualitas perkembangan anak di masa depannya sangat ditentukan oleh stimulasi yang diperolehnya sejak dini.

Belakangan ini, telah berbagai upaya yang dilakukan oleh pemerintah untuk meningkatkan kualitas pendidikan anak usia dini, hal itu secara tegas dinyatakan dalam Peraturan Pemerintah Nomor 2 Tahun 2019 yang merupakan penguatan terhadap Peraturan Presiden Nomor 59 Tahun 2017 tentang Pelaksanaan Pencapaian Tujuan Pembangunan Berkelanjutan, telah mengamanatkan penyediaan akses bagi anak laki-laki dan perempuan terhadap pendidikan anak usia dini yang berkualitas, inklusif, dan berkesetaraan dalam rangka mendukung pendidikan sepanjang hayat.

Akses terhadap pendidikan anak usia dini yang berkualitas harus dibarengi dengan manajemen yang professional. Suprihatin (2004) mengartikan manajemen merupakan serangkaian tahapan kegiatan untuk mencapai tujuan dengan mendayagunakan sumber-sumber yang ada sampai seoptimal mungkin. Hal yang sama diungkapkan oleh Fattah (2012) bahwa manajemen merupakan proses mengintegrasikan sumber-sumber yang tidak berhubungan menjadi system total untuk menyelesaikan suatu tujuan.

Tujuan dan manfaat manajemen pendidikan menurut Kurniadin dan Machali (2012) antara lain : (1) Tercapainya PAIKEM, yaitu proses pembelajaran yang aktif, inovatif, kreatif, efektif, menyenangkan; (2) Membantu anak dalam menggali potensi dirinya; (3) Untuk menunjang kompetensi professional sebagai pendidik dan tenaga kependidikan sebagai manajerial; (4) Bertujuan untuk mencapai pendidikan secara efektif dan efisien; (5) Untuk membekali tenaga kependidikan berupa teori tentang proses dan tugas administrasi pendidikan (6) Dapat mengatasi masalah kualitas pendidikan; (7) Untuk meningkatkan citra pendidikan yang positif, yaitu merencanakan pendidikan yang merata, bermutu, relevan dan akuntabel.

Hal yang sama diungkapkan oleh Fattah (2012) bahwa tujuan dan manfaat manajemen pendidikan dapat diuraikan sebagai berikut: (a) Terwujudnya suasana belajar dan proses pembelajaran yang aktif, inovatif, kreatif, efektif, dan menyenangkan; (b) Terciptanya peserta didik yang aktif mengembangkan potensi dirinya untuk memiliki kekuatan spiritual keagamaan, pengendalian diri, kepribadian, kecerdasan, akhlak mulia, serta keterampilan yang diperlukan dirinya, 
masyarakat, bangsa dan Negara; (c) Terpenuhinya salah satu dari empat kompotensi tenaga pendidik dan kependidikan; (d) Tercapainya tujuan pendidikan secara efektif dan efisien; (e) Terbekalinya tenaga kependidikan dengan teori tentang proses dan tugas administrasi pendidikan; (f) Teratasinya masalah mutu pendidikan.

Suyadi (2017) mengartikan manajemen PAUD sebagai suatu upaya mengelola, mengatur dan mengarahkan proses interaksi edukatif antara anak didik dengan guru dan lingkungan secara teratur, terencana, dan tersistematisasikan untuk mencapai tujuan Pendidikan Anak Usia Dini (PAUD). Tujuan manajemen PAUD adalah menjadikan satuan PAUD bisa berjalan secara efektif dan efisien. Secara umum, fungsi manajemen PAUD terdiri dari empat hal, yakni perencanaan, pengorgnisasian, pengendalian atau kontrol, dan pengawasan.

Suharti (2018) memaparkan terdapat delapan jenis-jenis manajemen PAUD, yakni: (1) manajemen promosi; (2) manajemen admnistrasi; (3) manajemen kurikulum; (4) manajemen tenaga kependidikan; (5) manajemen peserta didik; (6) manajemen sarana dan prasarana; (7) manajemen desain lingkungan; dan (8) manajemen penilaian. Kedelapan jenis manajemen administrasi tersebut sangat penting untuk diperhatikan keterlaksanaannya dalam pengelolaan satuan Pendidikan Anak Usia Dini untuk meningkatkan kualitas pendidikan.

Salah satu jenis manajemen yang cukup penting diperhatikan adalah manajemen administrasi. Menurut Ushansyah (2017) manajemen administrasi adalah segala sesuatu yang mencakup proses kegiatan yang terkait mengenai pendidikan berupa perencanaan, pengorganisasian, pengarahan, pengkoordinasian, pengawasan, pembiayaan, dan pelaporan, menggunakan fasilitas yang ada guna terwujudnya tujuan pendidikan secara efektif dan efisien.

Untuk mencapai tujuan pendidikan, pengelolaan administrasi yang baik sangat menunjang untuk keberhasilan dunia pendidikan. Oleh karena itu, administrasi yang digunakan dalam dunia pendidikan diupayakan memporoleh hasil yang sesuai dengan harapan. Adapun tujuan administrasi menurut Mahidin (2017) yaitu: (1) efektifitas produksi; (2) efisiensi; (3) kemampuan menyesuaikan diri; (4) kepuasan kerja.

Kegiatan dalam administrasi pendidikan yakni: (1) mengatur program pengajaran; (2) mengatur kesiswaan; (3) mengatur kepegawaian; (4) mengatur perlengkapan atau barang; (5) mengatur keuangan (Ushansyah, 2017). Komponen penting yang mendukung dalam instansi pendidikan yaitu kegiatan mengatur program pengajaran, untuk memperoleh pengalaman belajar yang sistematis dan efektif bagi pihak peserta didik diperlukan perencanaan skenario pembelajaran yang menjadi acuan dan pola pelaksanaan. (Dolong, 2016)

Skenario pembelajaran dapat membantu dalam administrasi kegiatan yang dilakukan siswa. Alwi, dkk (2018) mengemukakan beberapa kegiatan mengatur kesiswaan antara lain sebagai berikut: (1) perencanaan peserta didik dilihat dari jumlah peserta didik serta rasio perbandingan antara guru dan anak; (2) peserta 
didik yang tidak hadir tercatat dalam buku absensi; (3) pencatatan buku induk dan buku alumni merupakan bentuk pelaporan peserta didik; (4) pemberian ijazah kepada peserta didik sebagai bukti bahwa peserta didik telah menyelesaikan jenjang TK; dan (5) sekolah memberikan surat pindah kepada peserta didik yang pindah sekolah.

Adapun yang memegang peranan penting dalam keberhasilan lembaga pendidikan termasuk juga dalam organisasi pendidikan yaitu sumber daya manusia atau tenaga kepegawaian. Sebagaimana dalam Undang-undang Republik Indonesia Nomor 20 Tahun 2003 tentang Sistem Pendidikan Nasional, bahwa "Tenaga Kependidikan adalah anggota masyarakat yang mengabdikan diri dan diangkat untuk menunjang penyelenggaraan pendidikan". Meskipun tidak terlibat secara langsung dalam kegiatan pembelajaran, akan tetapi peran tenaga kependidikan sangat mendukung kegiatan belajar dan pelayanan pendidikan.

Salah satu bagian lagi dalam manajemen administrasi selain manajemen administrasi kesiswaan, tenaga pendidik, yakni manajemen administrasi sarana dan prasarana. Suharti (2018) berpendapat bahwa inventarisasi mengatur sarana dan prasarana bermanfaat untuk mencatat barang-barang serta mengatur daftar barang yang menjadi milik sekolah. Inventarisasi bertujuan untuk mengontrol barang yang sudah pernah diterima dan telah digunakan serta mencatat barang yang sudah tidak layak pakai. Dengan adanya inventarisasi pula dapat memudahkan dalam pengelolaan keuangan meliputi pemasukan dan pengeluaran. Menurut Hatta, dkk (2018) pengelolaan administrasi keuangan yang baik, harus didukung dengan pelaksanaan yang memadai. Bidang administrasi pendidikan secara khusus yang menangani hal tersebut adalah manejmen keuangan. Penggunaan uang pada lembaga perlu dipertanggung jawabkan guna tercapainya tujuan pendidikan. Adapun tujuan manajemen keuangan yaitu untuk mengelola hal-hal yang terkait dengan keuangan.

Berdasarkan observasi awal yang dilakukan di TK Amaliah, peneliti melihat pengelolaan administrasinya lengkap yang dibuktikan telah terakreditasi B. Perolehan hasil akreditasi tersebut asumsinya telah melalui beberapa tahapan berupa verifikasi berkas terkait mengenai manajemen administrasi. Selain itu, alasan lainnya karena peneliti tertarik akan tenaga kependidikan didalamnya karena di TK Amaliah tenaga pendidiknya bukan merupakan lulusan PAUD akan tetapi memiliki manajemen administrasi yang lengkap sesuai yang dipersyaratkan dalam indicator akreditasi satuan PAUD.

Dari latar belakang di atas maka permasalahan peneliti mengambil fokus kepada bagaimana proses kegiatan manajemen administrasi di TK Amaliah dalam mendukung peningkatan kualitas pendidikan anak usia dini.

\section{METODE PENELITIAN}


Jenis penelitian ini merupakan jenis penelitian deskriptif kualitatif. Sumber data dalam penelitian ini dan sekaligus menjadi informan yaitu kepala sekolah, guru dan operator di TK Amaliah kompleks Tamarunang Indah II, kelurahan Tamarunang, kecamatan Somba Opu, Kabupaten Gowa, Sulawesi Selatan. Sekolah yang menjadi lokasi penelitian dipilih berdasarkan kriteria: (1) Minimal telah menamatkan anak didik selama tiga tahun; (2) Dapat izin operasional dari dinas pendidikan; (3) Mudah diakses oleh peneliti. (4) Kepala sekolah dan guru bersedia menjadi informan penelitian.

Teknik pengumpulan data dilakukan menggunakan wawancara terstruktur, observasi dan dokumentasi. Data yang terkumpul dianalisis menggunakan teknik analisis data kualitatif model Miles dan Huberman, yakni dengan tahapan-tahapan: (1) reduksi data. Pertama, meringkas data yang diperoleh langsung darin informan. Kedua, dalam analisi selama pengumpulan data membuat catatan objektif, maksudnya mencatat sekaligus mengklarivikasikan dan mengedit jawaban atau situasi sebagaimana adanya. Ketiga, menuliskan apa yang terfikir oleh peneliti dalam sangkut paut dengan catatan objektif kemudian memisahkan antara catatan objektif dan catatan reflektif. Keempat, penyimpanan data. Kelima, analisis antar lokasi, ada kemungkinan bahwa studi dilakukan pada lebih dari satu lokasi atau dilakukan oleh lebih satu staf peneliti, selanjutnya peneliti menuliskan kembali catatan deskriptif, catatan reflektif; (2) penyajian data. Pada tahap ini peneliti banyak terlibat dalam kegiatan penyajian atau penampilan (display) dari data yang dikumpulkan dan dianalisis sebelumnya, mengingat bahwa penelitian kualitatif banyak menyusun teks naratif; dan (3) penarikan kesimpulan dan verifikasi. Kesimupulan awal yang telah dikemukakan sebelumnya masih bersifat sementara dan akan berubah bila ditemukan bukti-bukti kuat yang mendukung tahap pengumpulan data berikutnya. Proses untuk mendapatkan bukti-bukti inilah yang disebut sebagai verifikasi berkas. (Miles dan Huberman, 2009).

\section{HASIL DAN PEMBAHASAN}

Data yang didapatkan di lapangan diuraikan menjadi beberapa pembagian berdasarkan indikator manajemen administrasi meliputi: (1) Kegiatan mengatur program pengajar; (2) Kegiatan mengatur kesiswaan; (3) Kegiatan mengatur kepegawaian; (4) Kegiatan mengatur perlengkapan atau barang; dan (5) Kegiatan mengatur keuangan.

\section{Kegiatan Mengatur Program pengajaran}

Adapun kegiatan mengatur program pengajaran yang dilaksanakan di TK Amaliah yaitu sebelum dan awal tahun ajaran baru, kegiatan harian, kegiatan mingguan, kegiatan bulanan dan semester, dan kegiatan menjelang akhir tahun ajaran. Dalam pelaksanaan mengatur program pengajaran di TK Amaliah sudah tertata dengan baik, karena dalam proses pelaksanaannya turut melibatkan 
berbagai pihak terutama guru. Kecuali itu proses penyusunan kurikulum dan program pembelajaran yang dilakukan di TK Amaliah juga telah melalui tahapantahapan perencanaan, pengorganisasian, pelaksanaan, dan pengawasan.

Perencanaan pengajaran sangat diperlukan untuk menyukseskan proses pembelajaran. Menurut Dolong (2016), perencanaan pengajaran yang merupakan skenario pembelajaran menjadi acuan dan pola pelaksanaan program pengajaran bagi pihak pendidik, dan pengalaman belajar yang sistematis dan efektif bagi pihak peserta didik. Selain itu, program pengajaran harus disesuaikan dengan kurikulum yang berlaku.

Awal tahun ajaran baru di TK Amaliah mengatur program pengajaran, pihak sekolah dalam hal ini kepala sekolah beserta pendidik dan tenaga kependidikan bekerjasama dalam menyusun dan menentukan rencana pengajaran untuk tahun ajaran yang akan berjalan. Salah satu contohnya yaitu kelompok A yang pindah ke kelompok B dibuatkan daftar pemindahan kelompok serta bagi anak yang baru diterima dibuatkan daftar dan dimasukkan ke kelompok A. Selanjutnya kegiatan mengatur program pengajaran kegiatan harian di TK Amaliah meliputi; memeriksa rencana program pembelajaran harian yang telah dibuat, melaksanakan super visi kelas, mengawasi dan memecahkan masalah yang terjadi di TK setiap hari.

Kegiatan mengatur program pengajaran dalam pelaksanaan mingguan diantaranya seperti; mencatat murid dan guru maupun tenaga tata usaha yang tidak hadir di TK Amaliah, mengecek guru pada saat membuat rencana pembelajaran program harian (RPPH), serta kepala TK Amaliah memberikan bantuan berupa arahan dan memeriksa secara langsung RPPM yang telah dibuat oleh masing-masing guru.

Kegiatan bulanan dan semester di TK Amaliah membuat laporan bulanan, kepala TK membuat laporan bulanan keadaan anak didik, guru, petugas tata usaha, data pengangkatan, masa kerja, keadaan gedung, dll. Di TK Amaliah juga menyusun program semester dan membagikan buku raporan pencapaian perkembagan peserta didik (buku raport) yang dilaksanakan setiap semester.

Terakhir dalam kegiatan mengatur program pengajaran menjelang akhir tahun ajaran di TK Amaliah membuat laporan akhir tahun ajaran dan pemeriksaan raport yang dibuat guru serta menandatangani. Dengan pengelolaan administrasi pengajaran yang tertata dan lengkap maka akan berpengaruh terhadap peningkatan pendidikan anak usia dini sehingga dalam pelaksanaannya memudahkan pengajaran di sekolah.

\section{Kegiatan Mengatur Kesiswaan}

Dalam proses kegiatan manajemen kesiswaan, di TK Amaliah dilaksanakan kegitan pencatatan tentang anak didik sejak anak masuk, bahkan sejak anak tersebut mendaftarkan diri sampai meninggalkan sekolah yang meliputi pencatatan dan pelaporan dengan rincian sebagai berikut; awal tahun ajaran kegiatan 
pencatatan dinilai dari kegiatan kepala TK Amaliah membentuk panitia penerimaan untuk murid baru, mempersiapkan dan mengerjakan pengisian buku induk selama tahun ajaran, mencatat kehadiran anak dalam bentuk buku absensi anak, papan absensi anak, dan rekapitulasi absen anak dalam sebulan, penilaian perkembangan anak didik (dapat dilihat pada raport dan rekapitulasi perkembangan anak), terakhir mutasi anak atau perpindahan antar TK dicatat secara tertib.

Kegiatan akhir tahun ajaran di TK Amaliah yaitu dalam kenaikan kelas/ kelompok dari kelompok $A$ ke kelompok $B$ atau anak yang telah selesai di TK Amaliah. Anak-anak yang telah mencapai usia SD, pada akhir tahun ajaran kepala TK Amaliah memberikan surat keterangan (ijazah) bahwa peserta didik tersebut telah menyelesaikan pendidikan di TK Amaliah .

Selain pencatatan data dalam kegiatan administrasi di TK Amaliah, juga memiliki pelaporan di setiap unit kerja dalam pengelolah pendidikan. Adapun bentuknya yaitu laporan data/ informasi tentang peserta didik di TK Amaliah, dilaporkan ke organisasi/ yayasan penyelenggaraan dan Diknas setempat antara lain; penerimaan keuangan, pengelolaan keuangan, dan pertanggung jawaban.

Dari hasil pengamatan peneliti mengenai kegiatan mengatur kesiswaan dapat ditarik kesimpulan bahwa manajemen peserta didik keberadaannya sangat dibutuhkan di TK, karena peserta didik merupakan subyek dan obyek dalam proses transformasi ilmu. Manajemen peserta didik merupakan penataan dan pengaturan terhadap kegiatan yang berkaitan dengan peserta didik itu sendiri, mulai dari murid itu masuk sampai dengan keluar atau lulus dari TK. Manajemen peserta didik tidak semata-semata pencatatan data peserta didik, akan tetapi meliputi aspek yang lebih luas yaitu membantu upaya pertumbuhan dan perkembangan murid melalui proses pendidikan di TK, sehingga dapat meningkatkan kualitas peserta didik. (Noor, 2015)

\section{Kegiatan Mengatur Kepegawaian}

Dalam kegiatan mengatur kepegawaian di TK Amaliah telah dilaksanakan seperti; mengatur pegawai, merencanakan dan membentuk formasi guru, data guru honorer (buku honor guru), meningkatkan kesejahteraan personal TK Amaliah, menyusun tugas-tugas dan pembagian pekerjaan jika ada guru yang berhalangan (sakit, cuti, izin, dan lain-lain), supervise pembelajaran dan absen guru.

Hanafi (2018) dalam penelitiannya, mengemukakan bahwa untuk mengetahui administrasi kepegawaian dilapangan perlu memahami hal-hal sebagai berikut; (1) pengembangan struktur organisasi; (2) penggolongan jabatan dan perencaan gaji; (3) penarikan tenaga kerja yang baik; (4) seleksi pegawai; (5) perencanaan latihan jabatan; dan (6) perencanaan kenaikan pangkat.

Hasil penelitian Akilah (2017), menggambarkan pegawai merupakan kekayaan utama yang dimiliki organisasi yang harus dibimbing dengan baik. Oleh karena itu, sifat manajemen sumber daya manusia harus strategis bagi lembaga untuk mencapai tujuan yang telah ditetapkan. Peranan manajemen sumber daya manusia 
sebagai faktor sentral dalam organisasi dapat dikelompokkan menjadi bebebrapa peran, diantaranya peran administrasi manajemen sumber daya manusia, peran operasional manajemen sumber daya manusia, dan peran strategis manajemen sumber daya manusia.

\section{Kegiatan Mengatur Perlengkapan/Barang}

Kegiatan administrasi yang dilakukan di TK Amaliah terkait dengan perlengkapan/ barang di TK yaitu; mengatur administrasi buku pedoman, administrasi mengatur media atau alat peraga yang akan digunakan; mengatur pemeliharaan keberhasilan gedung dan keindahan halaman; pengadaan perlengkapan/ barang; mengatur inventaris tanah, gedung, dan perlengkapan yang ada di TK Amaliah.

Dari hasil penelitian Suharti (2018) dapat diketahui komponen dalam mengatur perlengkapan dan barang yaitu: (1) perencanaan perlengkapan/barang adalah segala kebutuhan yang diperlukan sekolah, perencanaan yang dilakukan sesuai basis sekolah (2) pertanggung jawaban perlengkapan/ barang adalah semua pihak lembaga yang bersangkutan, terhadap barang yang bergerak maupun yang tidak bergerak. (3) pengadaan perlengkapan/ barang ini melalui system perencanaan dan pengadaan yang harus dilakukan dengan cara berhati-hati, dalam pengadaan alat dan barang ini diperlukan pertimbangan yang lebih banyak yang bersifat edukatif. (4) inventarisasi dipergunakan untuk mencatat barang-barang serta menyusun daftar barang yang menjadi milik sekolah kedalam inventarisasi, tujuan dari inventarisasi adalah untuk ketertiban, serta pengontrolan dan pengecekan barang yang sudah diterima atau dipakai. (5) pemusnahan/penghapusan, terhadap barang yang sudah rusak atau tidak bisa dipakai lagi hanya dilakukan dengan cara membuang barang yang sudah tidak dipakai tanpa melakukan pencatatan.

Mengingat pentingnya perlengkapan/barang dalam proses pembelajaran maka peserta didik, tenaga pendidik dan kependidikan, di sekolah akan mempunyai peran penting secara langsung. Dengan pengelolaan yang baik, peserta didik akan lebih terbantu dengan dukungan perlengkapan/ barang pembelajaran. Dengan demikian pengelolaan perlengkapan/ barang yang tertata akan membantu dan mendukung dalam meningktakan kualitas pendidikan.

\section{Kegiatan Mengatur Keuangan}

Kegiatan administrasi keuangan di TK Amaliah sudah terlaksana dengan baik terlihat dari kepala sekolah dan bendahara bekerjasama dalam mengelola keuangan. Bentuk pengelolaanya yaitu mengatur sistem pembukuan kas dan prosedur pembukuan serta bertanggung jawab atas keuangan berdasarkan peraturan dan prosedur yang berlaku.

Bafadal (2012) menyatakan bahwa manajemen keuangan merupakan salah satu gugusan substansi administrasi pendidikan. Manajemen keuangan adalah 
salah satu bidang garapan administrasi pendidikan yang secara khusus menangani tugas-tugas yang berkaitan dengan pengelolaan keuangan yang dimiliki dan digunakan dalam lembaga pendidikan. Menurut para pakar administrasi pendidikan menyatakan bahwa "Manajemen keuangan pendidikan dapat diartikan sebagai keseluruhan proses pemerolehan dan pendayagunaan uang secara tertib, efektif, efisien, dan dapat dipertanggungjawabkan dalam rangka memperlancar pencapaian tujuan pendidikan.

Pembukuan di TK Amaliah adalah sebagai berikut: (1) System pembukuan dalam bentuk buku kas, kas besar dank kas kecil. Kas besar berfungsi untuk informasi mengenai pemasukan dan pengeluaran pendanaan. Sedangkan kas kecil, berguna untuk mencatat informasi mengenai pemasukan dan pengeluaran yang berasal dari kas kecil; (2) Prosedur pembukuan, terdiri dari tiga bagian yaitu untuk peserta didik atau orang tuan, sebagai laporan ke pusat (ketua yayasan) dan untuk arsip cabang, adapun bentuk pelaksanaann untuk orang tua atau peserta didik yaitu berawal dari transaksi penerimaan lanjut ke kuitansi putih, terakhir diberi kartu pemayaran uang sekolah. Untuk laporan ke pusat, bentuk pelaksanaannya mulai dari transaksi, kemudian kuitansi merah, lalu perincian peneriaan pembayaran sekolah, terakhir yaitu rekapitulasi kas besar. Untuk arsip cabang, bentuk pelaksanaannya yaitu dari transaksi penerimaan, selanjutnya kuitansi kuning, kemudian buku harian kas besar, terakhir buku kas untuk penerimaan uang sekolah.

Komariah (2018) menguraikan manajemen keuangan sekolah merupakan salah satu subtansi sekolah yang turut menentukan keberlangsungan penyelenggaraan pendidikan. Manajemen keuangan sekolah dapat dimaknai sebagai upaya kepengurusan atau ketatausahaan keuangan mulai dari pencatatan, perencanaan, pelaksanaan, pengawasan dan pertanggung jawaban. Kegiatan administrasi keuangan TK meliputi: (1) mengatur uang yang diterima; (2) Mengelola dan mengatur pengeluaran; dan (3) mengikuti prosedur yang berlaku saat mengelola dan mengatur keuangan. Untuk itu dalam pelaksanaannya, kepala sekolah, bendahara dan staf dituntut untuk senantiasa berpegang teguh pada prinsip-prinsip manajemen keuangan yakni: (1) transparan; (2) akuntabilita; (3) efektif; dan (4) efisien. Selain itu pengelola keuangan juga dituntut untuk mampu menguasai ruang lingkup manajemen keuangan sekolah yakni: (1) perencanaan anggaran; (2) mencari sumber dana sekolah; (3) penggunaan keuangan sekolah; (4) pengawasan dan evaluasi anggaran; dan (5) pertanggung jawaban keuangan sekolah.

Kesimpulan dari kegiatan mengatur keuangan yaitu dengan pengelolaan keuangan yang baik, pihak sekolah tidak selamanya hanya mendanai pembiayaan untuk sekolah saja, melainkan juga prestasi sekolah dapat meningkat, selain itu guru dan tenaga kependidikan akan mengalami peningkatan dalam melaksanakan tugasnya. Dengan mengatur keuangan yang baik tidak mustahil bagi sekolah memiliki kemandirian pendanaan, dapat memberdayakan masyarakat sekolah dan masyarakat sekitar, sehingga dapat meningkatkan kualitas pendidikan. 


\section{SIMPULAN}

Simpulan dari penelitian ini digambarkan bahwa TK Amaliah BTN Tamarunang Indah II, kelurahan Tamarunang, kecamatan Somba Opu kabupaten Gowa, Sulawesi Selatan secara umum menunjukkan bahwa satuan PAUD telah memenuhi indikator prasyarat dalam manajemen administrasi yaitu: (1) Kegiatan mengatur pengajaran; (2) Kegiatan mengatur kesiswaan; (3) Kegiatan mengatur kepegawaian; (4) Kegiatan mengatur perlengkapan/ barang; dan (5) Kegiatan mengatur keuangan. Dengan demikian, manajemen administrasi yang baik telah dilakukan oleh pihak sekolah sebagai salah satu upaya penting dalam peningkatan kualitas pendidikan anak usia dini. Hal ini pulalah yang menyebabkan akreditasi $B$ yang didapatkan TK Amaliah. Mereka hanya memiliki kekurangan pada linearitas tenaga pendidik yang bukan berasal dari alumni Jurusan PAUD.

\section{DAFTAR PUSTAKA}

Akilah, Fahmiah. (2017). Peran Manajemen Sumber Daya Manusia dalam Lembaga Pendidikan. Jurnal Manajemen Pendidikan IAIN Bone, 6 (1): 518-534.

Noor, Fu'ad Arif. (2015). Manajemen Peserta Didik Raudatul Atfal. Jurnal Komunakasi dan Pendidikan Islam, 4 (6): 129-164.

Bafadal, Ibrahim. (2012). Manajemen Peningkatan Mutu Sekolah Dasar: Dari Sentralisasi Menuji Desentralisasi. Surabaya: Bumi Aksara.

Alwi, Basse M., Ramadani, Suci., Suhanir., Safira, Zulaika., \& Herma, Tendri. (2018). Manajemen Peserta Didik pada Taman Pendidikan Anak Usia Dini Do'a Ibu. Nanaeke: Indonesian Journal Of Early Childhood Education, 1 (1): 53-62.

Dolong, Jefri. (2016). Sudut Pandang Perencanaan dalam Pengembangan Pembelajaran. Jurnal lingkungan kementrian agama islam, 5 (1): 65-76.

El Fiah, Rifda. (2017). Bimbingan dan Konseling Anak Usia Dini. Jakarta: PT Rajagrafindo Persada.

Fattah, Nanang. (2012). Landasan Manajemen Pendidikan. Bandung: PT Remaja Rosdakarya.

Hatta, Ermitati., Ananto, Rangga Putra., Yentifa, Armel., Maryanti, Maryati., \& Rissi, Dita Maretha. (2018) Pelatihan dan Pembenahan Manajemen Keuangan dan Administrasi Pada Yayasan PAUD dan TK Musa Enda Padang. Jurnal Akuntansi \& Manajemen, 13 (2): 17-24.

Hanafi, Muchammad. (2018). Peranan Administrasi Kepegawaian Pada Sekolah Menengah Kejuruan di Daerah Istimewa Yogyakarta. Jurnal Efesiensi-Kajian IImu Administrasi, 15 (1): 51-59. 
Kurniadin \& Machali. (2012). Manajemen Pendidikan: Konsep dan Prinsip Pengelolaan Pendidikan . Yogyakarta: Ar-Ruzz Media.

Komariah, Nur. (2018). Konsep Manajemen Keuangan Pendidikan. Jurnal Keislaman dan Peradaban, 6 (1): 67-94.

Khadijah. (2016). Pengembangan Kognitif Anak Usia Dini. Medan: Perdana Publishing.

Mahidin. (2017). Kajian Administrasi Pendidikan di Dunia Pendidikan. Jurnal AlIrsyad, 8 (1): 128-134.

Miles, Mathew B \& A. Michael Huberman. (2009). Qualitative data Analysis. di Terjh. Tjetjep Rohendi Rohidi. Jakarta: UI Press.

Suprihatin. (2004). Manajemen Sekolah. Semarang: UPT UNNES Press.

Suyadi. (2017). Manajemen PAUD TPA-KB-TK/RA. Yogyakarta: Pustaka Pelajar.

Suharti. (2018). Manajemen Pendidikan Anak Usia Dini (PAUD) dalam Rangka Meningkatkan Mutu Pembelajaran (Studi Pada PAUD Negeri Pembina Curup dan PAUD Pertiwi Kabupaten Rejang Lebong). Jurnal Studi Manajemen Pendidikan, 2 (1): 51-70.

Republik Indonesia. (2019). Peraturan Pemerintah No. 2 Tahun 2019 tentang Pelaksanaan Pencapaian Tujuan Pembangunan Berkelanjutan. Jakarta.

Ushansyah. (2017). Pentingnya Administrasi Sekolah Untuk Kemajuan Pendidikan. Ittihad: Jurnal Kopertais Wilayah II, Kalimantan, 15 (27): 13-22.

Tim Penyusun. (2003). Undang-Undang Republik Indonesia Nomor 20 Tahun 2003 Tentang Sistem Pendidikan Nasional. 